\title{
The Structure of Economic Attitudes of the Youth - Representatives of the Indigenous Small-Numbered Peoples of the Arctic Zone of the Russian Federation: Results of a Pilot Study
}

\author{
Vladimir S. Luzana, Natalia P. Koptseva*, \\ Ekaterina V. Zabelina ${ }^{\text {, }}$, Svetlana A. Kurnosova ${ }^{b}$ \\ and Irina A. Trushina ${ }^{b}$ \\ ${ }^{a}$ Siberian Federal University \\ 79 Svobodny, Krasnoyarsk, 660041, Russia \\ ${ }^{b}$ Chelyabinsk State University \\ 129 Br. Kashirinyh Str., Chelyabinsk, 454001, Russia
}

Received 09.06.2019, received in revised form 26.06.2019, accepted 08.07.2019

The article presents the results of a pilot study of economic attitudes of young people representatives of indigenous peoples of the Arctic zone (hereinafter - youth). The authors of the article used a multivariate questionnaire developed by O.S. Deineka and E. V. Zabelina as the main methodological tool to carry out the express diagnostics of economic attitudes. As a result, the article presents the structure of economic attitudes of youth.

In addition, using a factor analysis, the authors found four fundamental factors that should be considered as types of economic consciousness, but only one of them is financially confident and literate. The other three types are experiencing difficulties with knowledge in the field of economics, which can lead to dissatisfaction and disappointment of young people in this field in the future.

In conclusion, there are general conclusions and trends characterizing the tendency of young people from the indigenous peoples of the Arctic zone to passive, safe, and non-risky financial strategies.

Keywords: economic consciousness, economic behaviour, indigenous peoples of the Arctic zone, economic attitudes, attitude to money.

The study was carried out with the financial support of the Russian Foundation for Basic Research in the framework of the scientific project No. 19-013-00394 "Transformation of the economic behaviour of the indigenous minorities of the North living in the Arctic zone of the Russian Federation under globalization conditions."

Research area: culturology; economics.

(C) Siberian Federal University. All rights reserved

* Corresponding author E-mail address: decanka@mail.ru

ORCID: 0000-0003-3910-7991 (Koptseva); 0000-0002-0049-9417 (Lusan)

This work is licensed under a Creative Commons Attribution-NonCommercial 4.0 International License (CC BY-NC 4.0). 
Citation: Luzan, V.S., Koptseva, N.P., Zabelina, E.V., Kurnosova, S.A., Trushina, I.A. (2019). The structure of economic attitudes of the youth - representatives of the indigenous smallnumbered peoples of the Arctic zone of the Russian Federation: results of a pilot study. J. Sib. Fed. Univ. Humanit. soc. sci., 12(7), 1146-1162. DOI: 10.17516/1997-1370-0448.

\section{Introduction}

Social and cultural changes under the influence of globalization processes are critically affecting the indigenous small-numbered peoples (hereinafter referred to as the ISNP) that preserve their identity mainly through the traditional economy. Global warming and the active industrial development of the territories of traditional environmental management have a fundamental impact on them, thus making significant adjustments to the traditional methods of the economy management. In addition, the raw material orientation of the Russian economy suggests that in the short and long terms, the volume of industrial development of the territories of the traditional economy of the indigenous minorities of the North will only grow. The most noticeable changes are in the economic field, where there is unemployment, a decline in interest in entrepreneurial activity, a loss of the spirit of ownership, economic pessimism and apathy and an inability to plan your financial future.

At the same time, the study of economic consciousness of the indigenous smallnumbered peoples of the Arctic zone of the Russian Federation, especially young people, has been extremely limited. All this determines the relevance of the problem and the growing interest of researchers in it in recent years (Luzan, 2018; Koptseva, Sergeeva, Ermakov, 2018; Khariuchi, Petrova, 2014; Detter, 2018, etc.). A number of studies are devoted to the current status of the indigenous small-numbered peoples living in the Krasnoyarsk Territory and under the influence of global transformation processes (Koptseva, \& Kirko, 2014a, 2014b, 2014c; Reznikova et al., 2016: Kistova et al., 2016; Koptseva, 2014, etc.).

In this context, such a category as economic attitudes acquires a special role.

\section{Theoretical framework}

The references to attitudes are first encountered in psychology in the first third of the twentieth century and are still actively used in science. The definition made by M. Rokeach (Rokeach, 1968) is the most significant for this study. According to this definition, attitudes are "a relatively enduring organization of beliefs around 
an object or situation predisposing one to respond in some preferential manner" (Rokeach, 1968: 112).

Traditionally, there are three components in the structure of attitudes - cognitive, emotional and behavioural (Smith, 1996), which are closely related (Dinauer and Fink, 2005; Rosenberg, 1960) and can even conflict with each other (Armitage and Conner, 2000; Chaiken and Yates, 1985).

Economic attitudes, both individual and group, were most actively studied in the last quarter of the twentieth century. In particular, unemployment attitudes (Kalil et al., 2001; Lewis and Furnham, 1986), savings attitudes (Furnham, 1985), debt and consumption attitudes (Lea et al., 1995; Mewse et al., 2010) and investment attitudes (Antonides and Van Der Sar, 1990) have been studied. In addition, the effects of the interaction of various attitudes were analysed (Furnham, 1987).

In turn, economic attitudes, as a rule, are considered as a component of economic consciousness. At the same time, economic consciousness appears more as a subject of study of Russian economic psychology, in contrast to foreign psychologists, whose attention is focused mainly on the phenomenon of economic behaviour (Lewis et al., 1995).

In general, economic consciousness is customary to define as an integral system of reflection of objective economic reality consisting of various elements represented in psyche of an economic subject. These elements are in consistent hierarchical relations. One of the first definitions of economic consciousness in Russian research thinking was given by A. V. Filippov and S. V. Kovalev (Deineka, 1999), who interpret it as "a systemic component of consciousness, the highest mental level of reflection of economic relations by a socially developed person. Today it is customary to talk about individual and group economic consciousness, which includes conscious and unconscious components of the psyche, active and passive levels of reflection and regulation" (Deineka, 2011).

If we turn to the study of approaches to determination and justification of the structure of the economic consciousness of an individual, then it is necessary to indicate the approach developed by A.L. Zhuravlev and his colleagues. According to this approach, the main phenomena of the individual and group economic consciousness include:

1) social ideas about economic objects, both real and ideal;

2) attitude to economic objects, as well as opinions and judgments about them, their evaluation, etc.; 
3) social attitudes, stereotypes and prejudices associated with economic objects;

4) perceived emotions, feelings and experiences in general, associated with economic objects;

5) a phenomenon of social expectations, anticipation, forecast of economic changes, i. e. upcoming events related to economic objects;

6) social categorization and interpretation of economic and psychological phenomena, etc.

At this, the author emphasizes that the designated phenomena of economic consciousness do not have a common basis for their clear separation. As a rule, they partially overlap each other in their content and are designated by terms from different theoretical approaches (Zhuravlev, 2004).

Based on empirical research carried out by A. L. Zhuravlev and A. B. Kupreichenko (Zhuravlev, Kupreichenko, 2003) the authors identify the main components of economic consciousness: ideas (about oneself as an economic subject, about material well-being, wealth; about rich and poor people, about income activities, about property and owner); social settings of an individual for various forms of economic behavior; attitude of a person to money; psychological readiness for competition with other people in the economic sphere; individual orientation to economic values (Zhuravlev, Kupreichenko, 2003: 7).

Another model of economic consciousness distinguished by orderliness and logic is proposed by O.S. Deineka (Deineka, 2011). The researcher proposes to consider the components of economic consciousness at the intersection of two planes: activity passivity, a function of reflection - a function of regulation. Thus, there are four main quadrants of economic consciousness: economic perception; feelings and emotions in the economic sphere; economic ideas and economic thinking; economic motives, interests, norms and economic actions, deeds, activities. Economic attitudes within this model permeate several levels at once (feelings and emotions in the economic sphere, economic ideas and economic motives).

The study of interaction between the attitude to money and other psychological and economic phenomena is the most widespread. For example, A. Furnham (Furnham, 1996) studies the effect of work value on attitudes toward money (monetary attitudes). Von Stumm (Von Stumm et al., 2013) explores the impact of financial ability, attitude to money, and a socioeconomic status on the risk of failure to overcome unfavourable financial events. Thus, methodological approaches to the study of economic attitudes have been formed in psychological science. 
The features of ideology, culture, religion, and psychology of various ethnic groups (Pavlov, 2016) have a significant influence on the averaged economic behaviour. Along with the existence of individual features of economic behaviour and consciousness inherent in a person regardless of race, nationality or culture, the specific features of national psychology have always had a profound impact on economic activity and economic behaviour, as well as determined motivation and work ethic, attitude to social and income inequality, property and wealth (Brega, 2018).

The main factor reflecting the specifics of the national economy and determining the economic situation is economic culture. Economic culture is understood as "a set of social values and norms that are regulators of economic behaviour and play the role of social memory of economic development: contributing to (or interfering) translations, selection and renewal of values, norms and needs that function in the economic sphere and orient its subjects to these or other forms of the economic activity" (Arkhipova, 2001).

Economic culture is intangible and often subtle for analysis, but it significantly affects the nature of development of the economy of a country or a region. Its changes are very slow, the economy of modern countries has many features that relate it to the economic structure of the pre-industrial period. The development of the economy in any particular region is conditioned by the peculiarities of the national economic culture (Minnegaliev, Khairullin, 2010).

The heightened attention to the Arctic zone was historically determined mainly by the political and economic interests of using its rich resource potential, ensuring national security and strengthening international political influence. Over the past twenty years, with the development of mining and navigation technologies, the accents have only slightly changed: the main focus of attention on the Arctic Zone has shifted to the development of hydrocarbon reserves and the opportunities to increase deliveries along the Northern Sea Route. The consequences of "global warming" make the ecologically vulnerable Arctic Zone even more "beneficial" in terms of increasing the availability of resources (Frolov, 2015, Borisov, Pochukaeva, 2016).

The Arctic economy is based on two different ways of life - the ancient one, lived by the indigenous small-numbered peoples of the North (in many Arctic communities they continue to be numerically superior) and relatively young — lived by immigrants. These ways give it a peculiar multi-ethnic, multicultural dimension. Each way of life is characterized by its own system of norms and rules of economic behaviour. 
The traditional lifestyle of the indigenous small-numbered peoples of the North still retains a prestige value of generosity, informal rules for distributing prey by hunters among the whole community, implicit knowledge of the methods of hunting on sea whales, walruses and seals, and deer grazing. The aboriginal system for monitoring and using biological resources is integral, in contrast to the clear differentiation of environmental control services and environmental management agencies in state structures.

The traditional life sustenance of the indigenous peoples is gradually losing its role of a source of monetary income and employment, but at the same time it retains and even increases the value of the moral core, spiritual support for young aboriginal people (Piliasov, 2009). On the other hand, the modern youth of the Arctic Zone, thanks to the processes of globalization, share the same values, social expectations and behavioural norms as their peers in other geographic and cultural spaces - only $29 \%$ of young people wanted to live their lives just like their parents (Osipova, 2014). Industrialization of the northern territories had a huge impact on the lives of the indigenous minorities of the North, whose well-being directly depends on the ecological situation in the region, the fishing potential of the territory, as well as the external impact on their social way of life, customs and traditions (Leksin, Porfir'ev, 2015).

In this context, the socio-economic space of the Arctic zone of the Russian Federation is not single; it is a conglomerate of local environments with their own specific features. As a result, the scale of the territory under the study, the actual lack of internal unity and economic interconnectedness of the macroregion impose a need for a territorial approach to the organization of economic, sociological and psychological research works (Pavlenko et al., 2017).

In accordance with the Decree of the Council of Ministers of the USSR No. 12 dated 03/01/1983 "On Amendments and Additions to the List of Districts of the Far North and Localities Equated to the Districts of the Far North, approved by the Decree of the Council of Ministers of the USSR No. 1029 dated November 10, 1967", YamaloNenets Autonomous Okrug belongs to the regions of the Far North ["Consultant Plus" Reference Legal System], which determines special conditions of economy management and establishment of special benefits for the population, first of all, for the indigenous minorities.

The territory of the Yamalo-Nenets Autonomous Okrug (hereinafter - YNAO) is inhabited by representatives of many nations. Among them, the Nenets, the Selkups and the northern Khanty are indigenous. Today, the old-timed population of the Komi-Zyrians and Russians can be attributed to the indigenous ethnographic 
groups; their ethnocultural interaction with the autochthonous population was intense. Representatives of the Samoyed group of the Ural language family - the Nenets (Nenets, Nenei Nenets) are the most titular nation among the indigenous peoples.

In the territory of the Okrug there are two ethnographic groups of the Nenets: the Siberian tundra and the Siberian forest. 29,772 representatives of the Nenets nationality live in the YNAO, which is $5.69 \%$ of the total population; 9489 representatives of the Khanty (1.81 \%), and 1988 representatives of the Selkups (0.38\%), which makes this region especially significant in terms of the problem under consideration.

The interests of industrial development of the Yamal North inevitably collide with the interests of the traditional nature management of the indigenous small-numbered peoples. In a number of works, special attention is paid to the problem of interaction between the indigenous peoples and industrial companies (Zen'ko, 2001).

Despite the actions of the Law "On the Protection of the Original Habitat and Traditional Lifestyles of the Indigenous Small-numbered Peoples of the North in the Yamalo-Nenets Autonomous Okrug" (as amended in 2008), specialized laws, including the Law "On Reindeer Herding" [1998 YNAO Law], district targeted programs "Development of the Agrarian and Industrial Complex", "Provision of housing for citizens among the indigenous peoples of the North", "Culture, language, traditional lifestyle of the indigenous minorities of the North", the life expectancy of the Indigenous Minorities remains very low (Tishkov, 2016). So, $17 \%$ think that they only have enough money to buy food, and $5 \%$ think that it is not enough even for food. For those living in mono-ethnic Nenets settlements, the problem of poverty is even more acute (Dregalo, Ul'ianovskii, 2016).

\section{Statement of the problem}

In this pilot study, attention is focused on a wide range of economic attitudes (attitudes toward savings, investment, entrepreneurship, employment, financial institutions, consumption, etc.). The purpose of the study is to identify the structure of economic attitudes of young people - representatives of the indigenous smallnumbered peoples of the Arctic zone of the Russian Federation, as well as to interpret the results in the context of the current socio-economic situation.

\section{Methods}

In order to identify the structure of economic attitudes of young people representatives of the indigenous small-numbered peoples of the Arctic zone, the 
authors of the article used a multivariate questionnaire developed by O.S. Deineka and E.V. Zabelina as the main methodological tool to carry out the express diagnostics of economic attitudes. This questionnaire was chosen due to the fact that it allows us to comprehensively characterize the field of economic attitudes of a personality, since it includes various areas of economic behaviour: an owner (attitude to money and property, saving and investment behaviour), a consumer, an entrepreneur and an employee. At the same time, it is quite compact (21 statements) and is simple to process.

To reveal the structure of economic attitudes, an exploratory factor analysis was performed (using the principal component analysis with varimax rotation). When processing the obtained data, the Statistical Package for the Social Sciences (SPSS) 24.0 was used.

The pilot study was carried out by students from the educational institution of the Yamalo-Nenets Autonomous Okrug "Yamal Multidisciplinary College" (39 people: $38 \%$ of boys, $62 \%$ of girls, average age 18.6). The questionnaire was offered to students for filling in a paper form, the average filling time was 8 minutes.

\section{Discussion}

The structure of economic attitudes (types of economic consciousness of the youth) is confirmed by the study obtained by sampling students in central Russia. In the 2017 survey among 400 people, four factors were also found in the structure of economic attitudes, but the content of these factors was different (Zabelina, Deineka, Tsiring, 2019).

The first factor reflected the active position of an individual in the economic sphere and was called a "factor of attitudes of orienting activity in the economy." The second factor - a "factor of attitudes of economic planning and financial optimism", reflects the common optimism about economic well-being and setting for savings and control of finance, as well as the desire for financial literacy. The third factor is a "factor of trust/distrust in economic actors and institutions" and the fourth factor is a "factor of socio-economic comparison."

As a result of the study, the authors conclude about the existence of two strategies of psychological and economic adaptation among students. This adaptation is associated with entrepreneurship, active manifestation of their potential in the economic sphere and related to investing. That is, despite the common structure of economic attitudes, young representatives of the Indigenous Minorities are less confident in the economic future and are not ready to link their lives with entrepreneurship. 


\section{Results}

As a result of the factor analysis, four factors were identified in the structure of the economic attitudes among young people of the indigenous small-numbered peoples (Table 1).

Table 1. Factor representation of the structure of economic attitudes among young people of the indigenous small-numbered peoples

\begin{tabular}{|c|c|c|c|c|}
\hline \multirow{2}{*}{ Statement } & \multicolumn{3}{|c|}{ Factors } & 4 \\
\cline { 2 - 5 } & 1 & 2 & 3 & \\
\hline customer satisfaction &, 835 & & & \\
\hline confidence in future thanks to savings &, 823 & & & \\
\hline financial awareness &, 694 & & & \\
\hline distrust in banks, irrationality & &, 710 & & \\
\hline social responsibility of wealth & &, 705 & & \\
\hline primacy of earnings over health &,- 466 &, 654 & & \\
\hline negative attitude to entrepreneurs &,- 454 &, 557 & & \\
\hline willingness to invest & &, 517 & & \\
\hline activity in real estate & &, 506 & & \\
\hline consumer activity & &, 479 & & \\
\hline awareness of consumer irrationality & & &, 811 & \\
\hline rationality of purchases & & &, 686 & \\
\hline investment illiteracy & & &, 613 & \\
\hline activity, rationality in the banking sector &, 468 & &, 497 & \\
\hline value of independent economic achievements & & &, 495 &, 423 \\
\hline educative economic activity & & &,- 459 & \\
\hline significance of financial status & & & &, 700 \\
\hline economic ambitions & & & &, 671 \\
\hline financial optimism & & & &, 614 \\
\hline primacy of earning over vocation & & &, 504 \\
\hline desire to save money & & & \\
\hline
\end{tabular}

The first factor explaining $17.53 \%$ of the total dispersion included the following attributes: consumer satisfaction, confidence in the future due to savings, financial literacy, activity and rationality in the banking sector, primacy of earnings over health (with a negative sign) and negative attitude towards entrepreneurs (with a negative sign).

The content of this factor reflects the psychological type of young people who assess themselves as possessing knowledge in the financial sphere, depositing savings for the future, showing activity and rationality when working with banks, and those who are 
positively related to entrepreneurs aware of the value of health. All the attitudes listed above lead to satisfaction of this type of the youth in the sphere of consumption. This factor reflects the confident behaviour in the economic sphere, based on a competent attitude to finance and financial institutions.

The second factor explaining $14.7 \%$ of the total dispersion included the following indicators: distrust of banks, social responsibility of wealth, primacy of earnings over health, negative attitude to entrepreneurs, willingness to invest, activity in real estate, consumer activity.

This factor reflects the immature, contradictory attitude of young people to economic realities. On the one hand, young people of this psychological type are ready to be active in the economic sphere and even risk investing large sums, and are ready to work for money to the detriment of their own health. At the same time, they do not trust financial institutions and actors (for example, entrepreneurs), although they recognize their social responsibility. Most likely, this factor reflects "bewildered" young people who are not clearly aware of what needs to be done in order to be successful in the economic sphere.

The third factor explaining $11.6 \%$ of the dispersion included such economic attitudes as awareness of consumer irrationality, rationality of purchases, investment illiteracy, activity in the banking sector, value of independent economic achievements, and educative economic activity (with a negative sign).

This factor can characterize the psychological type of young people who understand the mechanisms of advertising and marketing well, strive for personal achievements in the economic sphere, but are not ready to receive relevant knowledge. Perhaps financial literacy training is not a value for students.

The fourth factor, which explains only $9 \%$ of the dispersion, includes significance of financial status, economic ambitions, financial optimism, primacy of earnings over vocation, a value of independent economic achievements and a desire to save money. The content of this factor reflects the psychological type of ambitious young people seeking to secure a high financial status in the future. They are optimistic, believe in success, but do not possess the knowledge and financial tools for this, except for the implementation of savings behaviour.

\section{Conclusion}

The obtained results are generally consistent with the results of previous studies. Thus, a comparative analysis of the economic attitudes of young people of the indigenous 
small-numbered people and young people in central Russia (Zabelina, Kurnosova, 2018) shows less activity and awareness of students of the indigenous small-numbered peoples when choosing banking services. They are characterized by lower cognitive activity in the economic sphere, as well as lower financial ambitions. They are less inclined to appreciate personal financial success and efforts to achieve it (Zabelina, Kurnosova, 2018). In the role of consumers, they are naiver and less practical than their peers in the field of shopping. At the same time, they value savings as a guarantee of confidence in the future, and are more inclined to save money for the future.

Thus, within the framework of the pilot study, four factors were identified in the structure of the economic attitudes of young people - representatives of the indigenous small-numbered peoples of the North, which can be considered as the types of economic consciousness. At the same time, out of four types of economic consciousness of young people - representatives of the indigenous small-numbered peoples of the North, only one is financially confident and literate. The other three types are experiencing difficulties with knowledge in the field of economics, which can lead to dissatisfaction and disappointment in this area in the future.

Thus, the study shows the lack of financial and economic literacy of young people - representatives of the indigenous small-numbered peoples of the Arctic zone. This fact entails potential problems not only associated with the lack of possible further economic efficiency of a particular person, but also with his worldview crisis in the context of the constant increase in various financial instruments, which largely determine both the individual and professional success of an individual.

Consequently, research on the economic attitudes of young people - representatives of the indigenous small-numbered peoples of the Arctic zone should be continued, for example, by increasing a sample group and/or conducting a qualitative study, in order to develop optimal mechanisms for the formation of financial and economic literacy of the youth.

\section{References}

Antonides, G. and Van Der Sar, N.L. (1990). Individual expectations, risk perception and preferences in relation to investment decision making. In Journal of Economic Psychology, 11, 2, 227-245.

Arkhipova, T.A. (2001). Ekonomicheskoe povedenie V rossiiskom transformiruiushchemsia obshchestve: sushchnost', cherty, napravleniia formirovaniia [Economic behavior in the Russian transforming society: essence, lines, directions 
of formation]. In Dissertatsiia kandidata ekonomicheskikh nauk po spetsial'nosti 08.00.01 [Dissertation of the candidate of economic sciences in the specialty 08.00.01]. Rostov-on-Don.

Armitage, C.J. and Conner, M. (2000). Attitudinal ambivalence: a test of three key hypotheses. In Personality and Social Psychology Bulletin, 26, 1421-1432.

Borisov, V.N., Pochukaeva, O.V. (2016). Vzaimosviazi faktorov razvitiia Arkticheskoi zony RF [Interrelations of factors of development of the Arctic zone of the Russian Federation]. In Problemy prognozirovaniia [Problems of Forecasting], 2, $59-68$.

Brega, G.V. (2018). Etnicheskie osobennosti ekonomicheskogo povedeniia [Ethnic features of economic behavior.]. In Izdatel'stvo "Prometei" [Publishing house "Prometheus"].

Chaiken, S. and Yates, S. (1985). Affective-cognitive consistency and thoughtinduced attitude polarization. In Journal of Personality and Social Psychology, 49, 1470-1481.

Deineka, O.S. (1999). Ekonomicheskaia psikhologiia: social'no-politicheskie problemy [Economic psychology: socio-political problems]. Saint-Petersburg, St. Petersburg State University.

Deineka, O.S. (2011). Ekonomicheskoe soznanie: fenomenologiia, struktura i potentsial razvitiia [Economic consciousness: phenomenology, structure and development potential]. In Kul'tura i ekonomicheskoe povedenie [Culture and economic behavior]. Moscow, Maks Press, 118-148.

Deineka, O.S., Zabelina, E.V. (2018). Rezul'taty razrabotki shkal'nogo mnogofaktornogo oprosnika dlia ekspress-diagnostiki ekonomicheskikh attit'iudov [The results of the development of a school multifactor questionnaire for express diagnostics of economic attitudes]. In Psikhologicheskie issledovaniia [Psychological Research], 11 (58), 9. Available at: http://psystudy.ru

Detter, G.F. (2018). Formirovanie funktsional'no polnoi innovatsionnoi infrastruktury $\mathrm{v}$ ekosisteme arkticheskikh regionov [Formation of a functionally complete innovation infrastructure in the ecosystem of the Arctic regions]. In Voprosy innovatsionnoi ekonomiki [Issues of Innovation Economy], 8 (1), 91-104.

Dinauer, L.D., Fink, E.E. (2005). Inter-attitude structure and attitude dynamics. In Human Communication Research, 31, 1-32.

Dregalo, A.A., Ul'ianovskii, V.I. (2016). Inertsionnye protsessy v obshchestvennom soznanii Severnogo regiona Rossii. Monitoring i otsenka razvitiia territorii Arkticheskoi 
zony [Inertial processes in the public consciousness of the Northern region of Russia. Monitoring and assessment of the development of the territory of the Arctic zone]. Arkhangelsk, izdatel'stvo "KIRA" [Publishing house KIRA], 304-306.

Frolov, I.E. (2015). Osvoenie rossiiskoi zony Arktiki: problemy vossozdaniia transportnoi i voennoi infrastruktur [Development of the Russian zone of the Arctic: the problem of recreating the transport and military infrastructures]. In Problemy prognozirovaniia [Problems of Forecasting], 6, 67-74.

Furnham, A. (1985). Why Do People Save? Attitudes to, and Habits of Saving Money in Britain. In Journal of Applied Social Psychology, 15, 5, 354-373.

Furnham, A. (1987). The structure of economic beliefs. In Personality and Individual Differences, 8 (2), 253-260.

Furnham, A. (1996). Attitudinal correlates and demographic predictors of monetary beliefs and behaviours. In Journal of Organizational Behavior, 17 (4), 375-388.

Kalil, A., Schweingruber, H.A., Seefeldt, K.S. (2001). Correlates of employment among welfare recipients: Do psychological characteristics and attitudes matter? In American Journal of Community Psychology, 29 (5), 701-723.

Khariuchi, G.P., Petrova, V.P. (2014). Nentsy v istorii Yamala [Nenets in the history of Yamal]. In Nauchnyi vestnik Yamalo-Nenetskogo avtonomnogo okruga [Scientific Herald of the Yamalo-Nenets Autonomous District], 3(84), 55-59.

Kistova, A.V., Zamaraeva, Iu.S., Pimenova, N.N., Reznikova, K.V., Koptseva, N.P., Seredkina, N.N. (2016). Regional Peculiarities in Modernization Processes within the Territories of Central Siberia. In International Review of Management and Marketing, 6(4), 857-865.

Komkov, N.I., Selin, V.S., Tsukerman, V.A., Goriachevskaia, E.S. (2016). Scenarnyi prognoz razvitiia Severnogo morskogo puti [Scenario forecast for the development of the Northern Sea Route]. In Problemy prognozirovaniia [Problems of Forecasting], 2, 87-98.

Koptseva, N.P. (2014). Expert analysis of the main trends of Northern Siberia's Indigenous small-numbered peoples economic development. In Economic-AnnalsXXI, (11-12), 93-96.

Koptseva, N.P., Kirko, V.I. (2014a). Ethic identification of indigenous people of the Siberian Arctic. In American Journal of Applied Sciences, 11(9), 1573-1577.

Koptseva, N.P., Kirko, V.I. (2014b). The information basis for formation of positive ethnic identities in the process of acculturation of indigenous peoples of the Arctic Siberia (Krasnoyarsk, Russia). In Life Sci J, 11(8), 479-483. 
Koptseva, N.P., Kirko, V.I. (2014c). Specificity of ethnogeny indigenous peoples by Central Siberia in the transition from the traditional type of society to modern society. In Life Sci J, 11(7), 409-413.

Koptseva, N.P., Sergeeva, N.A., Ermakov, T.K. (2018). Sovremennye sposoby etnicheskoi samoidentifikatsii na materiale analiza evenkiiskoi etnokul'turnoi gruppy [Modern ways of ethnic self-identification based on the analysis of the Evenki ethnocultural group]. In Spetsifika etnicheskikh migratsionnykh protsessov na territorii tsentral'noi Sibiri v XX-XXI vekakh: opyt i perspektivy [Specificity of ethnic migration processes in the territory of central Siberia in the 20th-21 st centuries: experience and prospects]. Krasnoyarsk: Izdatel'stvo: Sibirskii federal'nyj universitet, 195-198.

Lea, S.E.G., Webley, P., Walker, C.M. (1995). Psychological factors in consumer debt: Money management, economic socialization, and credit use. In Journal of Economic Psychology, 16 (4), 681-701.

Leksin, V.N., Porfir'ev, B.N. (2015). Nauchnyi i institutsional'nyi potentsial kompleksnogo razvitiia rossiiskoi Arktiki v sredne- i dolgosrochnoi perspective [The scientific and institutional potential of the integrated development of the Russian Arctic in the medium and long term]. In Problemy prognozirovaniia [Problems of Forecasting], 6, 58-66.

Lewis, A., Webley, P., Furnham, A. (1995). The new economic mind: the social psychology of economic behaviour, $332 \mathrm{p}$.

Lewis, A. and Furnham, A. (1986). Reducing unemployment: Lay beliefs about how to reduce current unemployment. In Journal of Economic Psychology, 7 (1), 75 85.

Luzan, V.S. Spetsifika realizatsii kul'turnoi politiki v sub'ektakh, obrazovannykh po natsional'nomu priznaku, i v mestakh kompaktnogo prozhivaniia korennykh malochislennykh narodov [The specifics of the implementation of cultural policy in the subjects formed on a national basis, and in areas densely populated by indigenous minorities]. In Liki kul'tury v epokhu sotsial'nykh peremen. Materialy Vserossiiskoi $s$ mezhdunarodnym uchastiem nauchnoi konferentsii [Images of culture in the era of social change. Materials of the All-Russian with international participation scientific conference]. Ekaterinburg: Izdatel'stvo: Ural'skii gosudarstvennyi pedagogicheskii universitet [Publisher: Ural State Pedagogical University], 165-169.

Mewse, A.J., Lea, S.E.G. and Wrapson, W.(2010). First steps out of debt. Attitudes and social identity as predictors of contact by debtors with creditors. In Journal of Economic Psychology, 31 (6), 1021-1034. 
Minnegaliev, I.M., Khairullin, A.G. (2010). Ekonomicheskaia mental'nost': sushchnost', struktura, rossiiskaia spetsifika [Economic mentality: essence, structure, Russian specificity]. In Sotsial'no-ekonomicheskie i tekhnicheskie sistemy [Socioeconomic and Technical Systems], 1.

Nattel, M. (2008). Neft', gaz i prava aborigenov v Arktike: opyt Severnoi Kanady [Oil, gas and aboriginal rights in the Arctic: the experience of Northern Canada]. In Etnograficheskoe obozrenie [Ethnographic Review], 3, 4-17.

Novikova, N.I. (2014). Okhotniki i neftianiki: Issledovanie po iuridicheskoi antropologii [Hunters and oilmen: A study on legal anthropology]. Moskva, izdatel'stvo "Nauka" [publishing house "Science"].

Osipova, O.V. (2014). Izmenenie zhiznennykh strategii i ekonomicheskogo povedeniia molodezhi Arktiki [Changes in life strategies and economic behavior of young people in the Arctic]. In Arktika i Sever [The Arctic Region and the North], 14.

Pavlenko, V.I., Dregalo, A.A., Ul'ianvskii, V.I., Kutsenko, S. Iu., Malinina, K.O., Balitskaia, S.M. (2017). Metodologicheskie osobennosti sotsial'no-ekonomicheskikh issledovanii Arkticheskoi zony Rossiiskoi Federatsii [Methodological features of socio-economic research in the Arctic zone of the Russian Federation]. In Izvestiia Komi nauchnogo tsentra UrO RAN [Komi Bulletin of the Scientific Center UB RAS], 1 (29). Syktyvkar.

Pavlov, K.V. (2016). Etnoterritorial'nye i natsional'nye modeli menedzhmenta i ekonomiki [Ethno-territorial and national models of management and economics]. In Ekonomika i upravlenie: teoriia i praktika [Economics and Management: Theory and Practice], 2 (2), 23-36.

Piliasov, A.N. (2009). I poslednie stanut pervymi: Severnaia periferiia na puti $k$ ekonomike znaniia [And the latter will be the first: the Northern periphery on the path to the economy of knowledge]. Moscow, izdatel'stvo Knizhnyi dom "LIBROKOM".

Reznikova, K., Seredkina, N., Koptseva, N., Zamaraeva, Iu. (2016). Regional specifics of social values and their impact on Central Siberian territories' modernization (based on research of Krasnoyarsk region). In Economic Annals-XXI, 160(7-8), 92-95.

Rokeach, M. (1968). Beliefs, attitudes and values: A theory of organization and change. San Francisco: Jossey-Bass.

Rosenberg, M.J. (1960). A Structural Theory of Attitude Dynamics. In Public Opinion Quarterly, 24, 319-340.

Smith, E.R. (1996). What do connection is mand social psychology offer each other? In Journal of Personality and Social Psychology, 70, 893-912. 
Tatarkin, A.I., Loginov, V.G. (2015). Otsenka prirodno-resursnogo i proizvodstvennogo potentsiala severnykh i arkticheskikh raionov: sostoianie i perspektivy ispol'zovaniia [Assessment of the natural resource and production potential of the northern and arctic regions: state and prospects of use]. In Problemy prognozirovaniia [Problems of Forecasting], 1, 34-44.

Tishkov, V.A. (ed.) (2016). Rossiiskaia Arktika: korennye narody i promyshlennoe osvoenie [Russian Arctic: Indigenous peoples and industrial development]. Moscow, Saint-Petersburg, izdatel'stvo Nestor-Istoriia [Nestor-History publishing house].

Von Stumm, S., Fenton O'Creevy, M., Furnham, A. (2013). Financial capability, money attitudes and socioeconomic status: Risks for experiencing adverse financial events. In Personality and Individual Differences, 54 (3), 344-349.

Zabelina E., Deineka O., Tsiring, D. (2019) Entrepreneurial attitudes in the structure of students' economic minds. In International Journal of Entrepreneurial Behavior \& Research. Available at: https://doi.org/10.1108/IJEBR-04-2018-0224.

Zabelina, E.V., Kurnosova, S.A. (2018). Osobennosti ekonomicheskogo soznaniia predstavitelei korennykh malochislennykh narodov Arkticheskoi zony: rezul'taty pilotnogo issledovaniia molodezhi [Features of the economic consciousness of the representatives of the indigenous peoples of the Arctic zone: the results of a pilot study of young people]. In Peterburgskii psikhologicheskii zhurnal [Saint-Petersburg Psychological Journal], 23. Available at: http://ppj.spbu.ru/index.php/psy/article/ view/203

Zen'ko, M.A. (2001). Sovremennyi Yamal: etnoekologicheskie i etnosocial'nye problemy [Modern Yamal: ethno-ecological and ethno-social problems]. In Issledovaniia po prikladnoi i neotlozhnoi etnologii [Research in Applied and Urgent Ethnology], 139.

Zhuravlev, A.L. (2004). Ekonomicheskaia psikhologiia v kontekste sovremennoi psikhologicheskoi nauki [Economic psychology in the context of modern psychological science]. In Problemy ekonomicheskoi psikhologii [Problems of economic psychology], 1. Moscow, Izdatel'stvo "IP RAN" [Publishing house "IP RAS”], 3-24.

Zhuravlev, A.L., Kupreichenko, A.B. (2003). Nravstvenno-psikhologicheskaia reguliatsiia ekonomicheskoi aktivnosti [Moral and psychological regulation of economic activity]. Moscow, izdatel'stvo IP RAN [Publishing house IP RAS]. 


\title{
Структура экономических аттитюдов молодежи - представителей коренных малочисленных народов
} Арктической зоны Российской Федерации: результаты пилотного исследования

\author{
В.С. Лузан ${ }^{a}$, Н.П. Копцева ${ }^{a}$ Е.В. Забелинаб \\ С.А. Курносова ${ }^{0}$, И.А. Трушина \\ ${ }^{a}$ Сибирский федеральный университет \\ Россия, 660041, Красноярск, пр. Свободный, 79 \\ бЧелябинский государственный университет \\ Россия, 454001, Челябинск, \\ ул. Братьев Кашириньх, 129
}

В статье представлены результаты пилотного исследования экономических аттитюдов молодежи - представителей коренных малочисленных народов Арктической зоны (далее - молодежь). В качестве основного методологического инструмента в статье использовался шкальный многофакторный опросник для экспресс-диагностики экономических аттитюдов, разработанньй О.С. Дейнека и Е.В. Забелиной. В результате в статье представлена структура экономических аттитюдов молодежи.

Кроме того, с помощью факторного анализа обнаружено четыре фундаментальных фактора, которые необходимо рассматривать в качестве типов экономического сознания, однако только один из них является финансово уверенным и грамотным. Другие три типа испытывают трудности со знаниями в области экономики, что может привести к неудовлетворенности и разочарованию молодежи в данной сфере в будущем.

В заключение обозначены общие выводы и тенденции, характеризуюшие склонность молодых людей из числа коренных малочисленных народов Арктической зоны к пассивным. безопасным, не рисковым финансовым стратегиям.

Ключевые слова: экономическое сознание, экономическое поведение, коренные малочисленные народы Арктической зоны, экономические аттитюды, отношение к деньгам.

Исследование выполнено при финансовой поддержке РФФИ в рамках научного проекта № 19-013-00394 «Трансформация экономического поведения коренных малочисленных народов Севера, проживающих на территории Арктической зоны Российской Федераичии в условиях глобализаџии».

Научная специиальность: 24.00.00 - культурология; 08.00.00- экономические науки. 